\title{
Chapter 3 \\ Mobility and Migrations in the Rural Areas of Mediterranean EU Countries
}

This chapter focuses on the ambivalent nature of contemporary migrations in European rural areas. The growing presence of immigrants in these areas is a direct result of the restructuring of agriculture and global agri-food chains. Evidence indicates that while agricultural work and rural settings are decreasingly attractive to local populations, they represent a favourable environment to international newcomers, due to the higher chances to access livelihood resources. The non-visibility and informality that characterise rural settings and agricultural work arrangements provide on the one side opportunities for employment, while also fostering illegal labour practices and situations of harsh exploitation.

The specificities of the Mediterranean migration model are assessed accordingly, followed by a more in-depth analysis of the agricultural sector and the broader rural world in Greece, Spain and Italy.

\subsection{Introduction}

This chapter focuses on the ambivalent nature of contemporary agricultural migration in European rural areas. Rural immigrants can be viewed as either seasonal agricultural workers or as new citizens offsetting declining local populations and revitalizing the rural world.

The framework described in Chap. 2 detailed the reconfiguration of EU agriculture and the important implications on its agricultural workforce, which in recent decades has shifted from family labour to a salaried, foreign one. In the context of a progressive rural exodus of local populations, the relative proportion of immigrants has been raising rapidly in European farming and rural realities.

Evidence indicates that while agricultural work and rural settings are decreasingly attractive to local populations, they represent a favourable environment to international newcomers, due to easier chances to access livelihood resources compared to urban areas. Furthermore rural realities offer degrees of non-visibility and 
informality, which help accommodate the needs of several immigrants. On the other hand, these same realities foster illegal labour practices and situations of harsh exploitation, as will be analysed subsequently.

Apart from filling the gaps in agricultural labour markets immigrants play multifunctional roles in rural settings, and their contributions are often vital to agricultural farms and rural societies, which in the last decades have undergone intense economic, demographic as well as socio-cultural decline.

While the presence of immigrants is visible throughout rural areas in Europe, it is particularly visible on the Mediterranean rim, where the demand for agricultural labour remains high while the decline and ageing of rural populations are particularly worrying.

Typically associated with emigration, the EUMed regions have turned within a few decades into an area of transition. They have eventually become a destination in its own right. Immigration to rural areas of the EUMed started in the 1980s and has expanded ever since. During the recent financial crisis, intense immigration has represented a key factor of resilience for the agricultural sector and the rural world, as it has enabled many farms, rural villages and agricultural enterprises to remain alive and productive throughout difficult times.

This chapter starts by providing a basic understanding of the growing centrality of immigrant workers in agriculture; the specificities of the Mediterranean migration model are then assessed, followed by a more in-depth analysis of the agricultural sector and the broader rural world in Greece, Spain and Italy. In next chapters we will further focus on the more marginal, isolated, remote areas of the EUMed where the contributions of immigrants are critical for the sustainability and reproduction of local rural societies.

\title{
3.2 Shifting Human Landscapes: The Growth of Immigration in Agriculture
}

\author{
According to Martin (2016: IX):
}

\begin{abstract}
Agriculture, the production of food and fiber on farms, employs a third of the world's workers, more than any other industry. An increasing share of the workers employed in industrial-country agriculture are hired or wage workers, and many of these are international migrants from poorer countries.
\end{abstract}

This phenomenon does not only apply only to industrialized Western countries, but it seems to be widespread throughout the globe as foreign workers are frequently, and increasingly, part of the agricultural workforce even in poorer and middleincome countries (OECD 2018; Zuccotti et al. 2018; SOFA 2018; UN DESA 2017; ILO 2015). 
Box: Agricultural Migrant Labour in the US and Canada (SOFA 2018) Foreign labour constitutes the backbone of agricultural production in Canada and the United States. The agricultural sector in Canada relies heavily on the labour of temporary migrant agricultural workers. Roughly $75 \%$ of labour gaps in the agricultural sector is filled by this group. Migrant workers have played a fundamental role in helping the country's horticultural industry to compete in the global food economy. In fact, evidence shows a direct link between the growth of Canadian horticultural exports and the rising number of migrant workers.

In the United States approximately $70 \%$ of farm workers are Mexican (the data is almost $90 \%$ in agriculture intensive California). When the inflow of Mexican immigrant workers decreased during the 2002-2014 period due to stricter border controls, shortages in agricultural labour resulted in significant losses to American farmers. Calculated revenue losses amounted to USD 3 billion for each year between 2002 and 2014 .

Europe is not an exception to this and today, in many parts of the EU, immigrant workers (with or without legal status) constitute a consistent portion of the agricultural labour force. Disentangling the critical relationships between the conditions of agricultural work, rural development paradigms, labour markets and migration policies, represents thus a necessary step to understand ongoing dynamics.

On the one hand, farmers are increasingly squeezed by price competition and thus pushed towards consistent cuts in production costs, which eventually leads them to hire a cheap and flexible labour through an immigrant workforce. On the other hand, agriculture provides immigrants with better access to affordable basic resources like food and shelter and accessible employment and income-earning opportunities for low-skilled people originating from poorer regions. Rural areas and the agricultural sector also offer degrees of non-visibility and informality that help accommodate the needs of irregular migrant citizens and workers. These informal features might represent critical constraints to the integration of foreign workers in the agrarian world, contributing to undermining the social acceptance as well as the sustainability of agricultural systems (Gertel and Sippel 2014; Corrado et al. 2016; Farinella et al. 2017). These features are particularly specific to the EUMed context where, together with domestic work, agriculture is the main sector recruiting migrants without regular contracts (OECD 2012).

National governments respond to farm labour shortages through forms that range from; high tolerance of informal work in agriculture (meaning there may be little surveillance of immigration status in areas and sectors where there is a high labour demand) to increased attention to legal status once the harvest season is over. Policies that regulate the entry of seasonal workers ("quota policies"), and their ambiguous enforcement, have generated a lot of controversy and conflict, as these are mostly oriented to favour and protect local farms rather than their workers, of immigrant origin. Policies are not designed to counter the agricultural squeeze of 
farmers as a consequence of the global mechanisms of agri-food supply chains; rather, they incentivize agricultural companies to exploit workers, increasing control, surveillance and blackmail mechanisms. According to Martin (2016: X).

Many governments enact protective labour laws after particular incidents involving farm worker protests or injuries. Few have policies to encourage farm employers to abide by these laws and raise labor standards and productivity over time so that agriculture provides higherwage and safer jobs for more skilled workers. Instead, many governments tolerate unauthorized workers and do not adequately protect guest workers, leading to substandard housing and other deficiencies.

Informality is a tolerated factor and is produced and reproduced through labour policies that help farms contain production costs, compressing "living labour" and consequently wages. Apart from the high level of informality and precariousness that characterize several agrarian settings, immigrant workers are also difficult to reach for activists, civil society, institutional controls and researchers alike for several social, cultural as well as logistical matters, including the effective awareness of their rights.

\subsection{A Mediterranean Model of Migration}

In geo-global politics, southern Europe plays the role of a semi-peripheral zone (Arrighi 1985). From the beginning of the twentieth century until the 1970s, southern European countries were places of emigration, characterized by internal flows, from rural areas to urbanized and industrial ones, and external flows towards other countries. In the last century southern Europe has mutated from a region of emigration, to an area of transit of migrants heading towards northern Europe. As from the 1980s Southern European countries have become a destination for immigrants preceeding from poorer southerner and eastern regions. ${ }^{1}$

The transition described above has been especially evident for EUMed countries, Greece, Spain and Italy, which are recently facing intense rates of migrant inflows (King et al. 2000; de Zulueta 2003; Schmoll et al. 2015). In order to explain this phenomenon we need to refer to what different authors have called the "Mediterranean model of migration", in which seasonal migrant workers have replaced local workers in many low-paid manual and unskilled jobs, for example as domestic workers, porters, agricultural laborers, or unskilled manufacturing (BaldwinEdwards and Arango 1999; King et al. 2000).

The emergence of a such model needs to be investigated in light of the changes that have characterized production systems for the Mediterranean countries since the 1970s, in the transition from the fordist model of production to the post-fordist one,

\footnotetext{
${ }^{1}$ The first laws that concerned immigration were developed in 1985 in Spain, 1986 in Italy and 1991 in Greece. The case also applies to Ireland and Scotland, which have also turned into countries of immigration in recent decades (Jentsch and Simard 2009).
} 
in which labour flexibility was to become more relevant. In the Mediterranean labour market. This has meant a push towards low wages, informal and precarious work, and growing degrees of informality and flexibility especially where labour is mostly physical and unskilled.

As Mingione (1995) highlights for southern Italy, the local labour market was characterized by a dualistic nature, with protected employment conditions in the public sector, and informal, precarious, and underpaid employment conditions for unskilled work in the private sector (i.e. construction, domestic work, and agriculture). Moreover, the entrepreneurrial fabric characterized by small and medium family businesses contributed to encouraging the demand for seasonal, cheap and mostly unskilled labour.

In such a framework, the interconnections between internal and international migrations have characterized the development of EUMed countries. As local labour markets are affected by out migration the labour supply is substituted through new flows of workers internally and transnationally. In the aftermath of the World War II mass-migration from Southern to Northern European countries resulted in a "reserve army" for the mining and industrial sectors of Northern Europe (Castles and Kosack 1973; Piore 1979; Pugliese 1993; for a discussion see King 2000). Most of these workers, together with their families, originated from poor rural areas, often from Southern regions of EUMed countries. In the 1960s, the modernization processes that took place in EUMed increased the levels of income and livelihoods reducing the development gap between Northern and Southern Europe, which contributed to migratory patterns. Southern European countries developed into industrialized areas, with increasing labour demands. This created new patterns of internal migration similar to the EU-wide pattern described above. In Italy and Spain grants began moving from the rural South to the Industrial North. According to King (2000: 10):

this movement involved the transfer of mostly unskilled and poorly educated workers from low-productivity agricultural jobs to high-productivity industry and services and this migration was fed by a buoyant rate of demographic growth which sustained 'unlimited supplies of labour' (Lewis 1958).

The struggles of workers in the 1970s broke this system as they refused to be "squeezed" in this way. Meanwhile, the rural exodus dried up, also due to falling birth rates, in particular in the South and in general in rural areas. Throughout these recent decades, while the agricultural sector decreased consistently in its relative importance within the EU economy, it nonetheless continued to demand a seasonal, flexible and precarious workforce, as agriculture has become decreasingly attractive to the local populations.

In the EUMed rural settings affected simultaneously by an economic and demographic crisis the relationships between patterns of emigration and those of immigration became critical. As Table 3.1 and Fig. 3.1 show the rate of population aged over 65 years has increased in the last decades: in 2017 the 65 years old represent $23 \%$ of total population in Italy, 20.4\% in Greece and $19.4 \%$ in Spain. In the 1960s this percentage was less than $10 \%$. In the same period, the rural population decreased and the international migration stock strongly increased. 
Table 3.1 Recent demographic trends in EUMed countries

\begin{tabular}{|c|c|c|c|c|}
\hline \multirow{2}{*}{\multicolumn{5}{|c|}{ Rural population }} \\
\hline & & & & \\
\hline \multirow[t]{2}{*}{2017} & $\%$ & 20 & 29,9 & 21,3 \\
\hline & Amount & 9.277 .148 & 18.078 .231 & 2.289 .387 \\
\hline \multirow[t]{2}{*}{2000} & $\%$ & 23,7 & 32,6 & 27,1 \\
\hline & Amount & 9.630 .000 & 18.664 .484 & 2.948 .257 \\
\hline \multirow[t]{2}{*}{1990} & $\%$ & 24,7 & 33,3 & 28,5 \\
\hline & Amount & 9.580 .406 & 18.872 .760 & 2.909 .451 \\
\hline \multirow[t]{2}{*}{1960} & $\%$ & 43,4 & 40,6 & 44 \\
\hline & Amount & 13.227 .520 & 20.400 .656 & 3.671 .291 \\
\hline \multicolumn{5}{|c|}{ International migration stock } \\
\hline \multirow[t]{2}{*}{2015} & $\%$ & 12,7 & 9,7 & 11,3 \\
\hline & Amount & 5.852 .953 & 5.788 .875 & 1.242 .514 \\
\hline \multirow[t]{2}{*}{2000} & $\%$ & 4,1 & 3,7 & 10,1 \\
\hline & Amount & 1.657 .285 & 2.121 .688 & 1.111 .665 \\
\hline \multirow[t]{2}{*}{1990} & $\%$ & 2,1 & 2,5 & 6,1 \\
\hline & Amount & 821.605 & 1.428 .219 & 618.139 \\
\hline 1960 & Amount & 210.897 & 459.553 & 52.495 \\
\hline \multicolumn{5}{|c|}{ Population over 65} \\
\hline \multirow[t]{2}{*}{2017} & $\%$ & 19,4 & 23 & 20,4 \\
\hline & Amount & 9.051 .923 & 13.939 .689 & 2.194 .721 \\
\hline \multirow[t]{2}{*}{2000} & $\%$ & 16,7 & 18,1 & 16,4 \\
\hline & Amount & 6.776 .002 & 10.333 .787 & 1.770 .442 \\
\hline \multirow[t]{2}{*}{1990} & $\%$ & 13,4 & 14,8 & 13,5 \\
\hline & Amount & 5.069 .944 & 8.425 .807 & 1.381 .186 \\
\hline \multirow[t]{2}{*}{1960} & $\%$ & 8,2 & 9,5 & 7,0 \\
\hline & Amount & 2.494 .868 & 4.766 .245 & 587.257 \\
\hline
\end{tabular}

Source: Worldbank - https://data.worldbank.org/indicator/

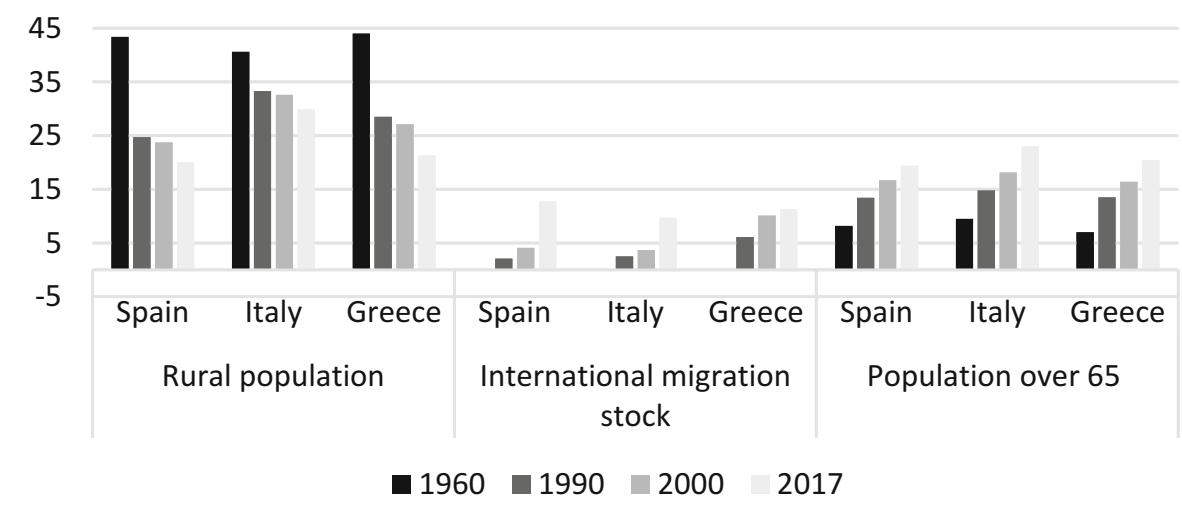

Fig. 3.1 Recent demographic trends in EUMed countries (\%). (Source: Our re-elaboration on Worldbank data, https://data.worldbank.org/indicator) 
Rising educational and living standards, the decreasing interest in manual work vis-à-vis other employment opportunities, and changes in the social and economic system (with the growing rates of local women in workforce, for example) has caused new needs for care workers in the private sector. The functioning of the Mediterranean model of welfare is characterized by a mix of state, market and family, with poor levels of public services, and the centrality of the family, and of women in particular, in the provision of care for the elderly and children (Ferrera 1996; Martin 1996; Pugliese 2000; Naldini 2003). As ironically noted by some researchers (Salazar Parreñas 2001; Ambrosini 2013), the growing amount of working women creates a new labour market for other women, usually immigrants who replace them in domestic labour, including in rural communities, where foregin caretakers and domestic workers upport local households and communities.

Today, the southern labour market still remains dualistic, with protected jobs in the public sector and informal and unstable, underpaid and unskilled work in most private sector employment (construction, tourism, care-giving, and agriculture).

Since the 1990s, the restriction of public spending reduced opportunities in public sector employment. These cuts were evident especially in southern regions, where public personnel typically exceed the real work needs. Emigration became more intense, while the private sector continued to demand for manual, unskilled and temporary workers in agricultural, but also in domestic work, private care, tourism and catering, construction. Immigrants eventually came to fill the gaps left by declining local populations and changing labour patterns, for cheap and flexible labour (Mingione and Quassoli 2000; King 2000; Osti and Ventura 2012).

Given the generalized informalization and downward trend in wages (especially for manual work with low productivity in services, agriculture and construction) over several decades, the EUMed has seen many rural areas transition from net-emigration to net-immigration regions.

According to King (2000: 14) this model of migration in the EUMed today is characterized by these features:

1. A kaleidoscope of different nationalities: while in the past migrations saw the predominance of specific groups depending on the destination countries. The multiplicity and heterogeneity of migrant nationalities today is stratified in a local labour market segmented by ethnic groups (called the "ethnicization" of the labour market, e.g., specific jobs are carried out mostly by workers coming from the same countries of origin.

2. Highly gender-specific flows from different countries: while previous migration involved male workers, recent migrations are mixed and segmented in relation to the kind of job. Many authors have reported over this territorial reconfiguration of ethnic as well as gender specialisation, with distinct communities occupying specific ecological and productive rural niches (Schrover et al. 2007; Bell and Osti 2010; Ambrosini 2013).

3. An increasing proportion of urban, educated persons: while in the sixties migrants were typically poor, less-educated and less-qualified, since the eighties the regional and social origins of migrants have become varied and stratified. 
Migrants come from both rural and urban regions, with differentiated ages and higher levels of education. The work they are undertaken is often under-qualified compared to the work in the country of origin or to their level of education. Agriculture often remains often a refuge sector for the poorest and least educated immigrants

4. High levels of "clandestinity and irregularity", whereby the labour market has "become a global 'industry' with its own economic logic and market characteristics, with high and increasing levels of illegality as well as of informality (Castles and Miller 1993; King 2000: 13).

\subsection{Migrant Workers in EU Mediterranean Agriculture: Some Common Features}

Farm labour in the EU is undergoing a long-term decline; in 2017 the EU agricultural sector emploied about 8.9 million people, almost a fourth less $(-25.5 \%)$ than it did in 2005. This decline is mostly due to two complementary and opposite trends, rising agricultural productivity due to mechanisation has reduced the need for labour in some areas, while land abandonment has decreased options for labour in others. While family labour in agriculture has been constantly reducing, opportunities for hired labour have proportionally grown; during recent years (2011-2017), hired labour has increased by $1 \%$ per year on average (Natale et al. 2019).

This phenomenon is common through the globe, as the International Labour Organization (ILO) reported at $40 \%$ the rate of hired or wage workers over employees in agriculture in the world in early 2000 (Pigot 2003). The reconfiguration of agriculture have thus carried relevant implications on the agricultural workforce, which in recent decades has shifted from mostly a family one, to hired, salaried workers, which have eventually shifted from a local to foreign ones. As a result agricultural activities today in Europe are increasingly carried out by immigrants.

In these areas industrial and commercial agriculture request wage workforce for harvesting in fruit and horticulture, as well as in labour-intensive crop and livestock farms. Due to its characteristic features (seasonality, high-intensity, manuality, low-skilled, mobility), agriculture in Mediterranean Europe represents an entry sector into the local labour market. The little interest of native workers provides little room for competition, and the greater tolerance for informal contractual conditions provide further elements for newcomers to seek opportunities in agriculture. Today more than a third of the officially employed agricultural workforce in Greece, Spain and Italy is of foreign origin (Collantes et al. 2014; Kasimis et al. 2010; Caruso and Corrado 2015; Corrado 2017; Papadopoulos and Fratsea 2017; Nori 2017).

Estimating the weight of migrant labour in agriculture is though very complex due to the high level of informality, and the heterogeneity in the quality and type of migration statistics available. In 2013, CREA estimated that $37 \%$ of agricultural 
Table 3.2 \% immigrant workers in EUMed countries

$\%$ Employed persons with foreign citizenship on total employed persons ${ }^{\mathrm{a}}$

\begin{tabular}{l|l|l|l|l}
\hline & EU-28 & Spain & Italy & Greece \\
\hline 2017 & 8,0 & 11,1 & $10,6\left(16,6\right.$ in agriculture $\left.{ }^{\mathrm{b}}\right)$ & 5,7 \\
\hline 2008 & 6,6 & 13,9 & 7,4 & 6,6 \\
\hline$\%$ Immigrants on wage labourforce in agriculture, $(\text { estimates })^{\mathrm{c}}$ & Greece \\
\hline \multicolumn{7}{l}{} & Spain & Italy & $>50$ \\
\hline 2013 & 24 & 37 & 17 \\
\hline 2008 & 19,1 & 19,4 &
\end{tabular}

Source:

${ }^{a}$ Eurostat - https://ec.europa.eu/eurostat/web/migrant-integration/data/database

${ }^{b}$ Ministero del Lavoro (2018), Eighth Annual Report on Foreigners in the Italian Labour market,

${ }^{c}$ Data sourced from Caruso and Corrado (2015). For Spain: OMT, Observatorio Mercado del

Trabajo. Madrid; OPI, (2014). Observatorio Permanente de la Immigraciòn. Madrid; For Italy:

CREA (2015); For Greece: HELSTAT, (2013). Hellenic Statistical Office. Athens

salaried workforce in Italy was of immigrant origin. Using the ISTAT sample survey on the labour force, in 2017 the Italian Ministery of Labour estimates the proportion of immigrants to be $16 \%$. The Labour Market Observatory (OMT) in Spain reports this rate to be $24 \%$ in 2013, while the Hellenic Statistical Office (ELSTAT) indicates that more than half of the salaried workers in agriculture are of foreign origin (Table 3.2).

In the last decade, after the financial crisis in 2008, intense immigration has represented a key factor of resilience for the agricultural sector and the rural world in these countries, as it has enabled many farms, rural villages and agriculture enterprises to remain alive and productive throughout difficult times (Kasimis 2010; Sampedro 2013; Collantes et al. 2014; Caruso and Corrado 2015; Schmoll et al. 2015; Nori 2017).

Conversely, and perhaps ironically given the worsening labour conditions, the rural world has also played a relevant role in enhancing the resilience of immigrant communities to the recent economic recession, following the worsening of living conditions in their home regions or of employment opportunities in destination urban areas. The majority of immigrant workers have recently found employment in EU rural areas rather than in the traditional urban migration centers, with important proportions finding work in even more peripheral parts of rural areas of the EU, for example in the mountainous or island rural communities (Jentsch and Simard 2009; Kasimis and Zografakis 2012; Colucci and Gallo 2015).

This may be because Mediterranean agriculture is a labour niche providing immigrants with better access to affordable basic resources like food and shelter and to more accessible employment opportunities. Mediterranean agriculture allows migrants to find options for employment and income, while cutting down on expenses as they build savings or send remittances.

These areas also offer degrees of non-visibility and informality that help accommodate their needs for decreased surveillance by the state, while creating as well the 
enabling environment for illegal practices and harsh exploitation, as it will be assessed.

Workforce in EUMed agriculture is also characterized by strategies of circular mobility, with workers moving between the different production areas according to seasonal peaks for labour, while moving back home when demand is low. The majority of workers in circular migration patterns come from Eastern Europe and the Balkans, as they face less trouble when it comes to documentation and visa permits and also because transportation costs are lower. The different capacities, opportunities and rights characterizing citizens proceeding from different regions depend on the different legislative and political agreements their countries of origin have stipulated with the EU or with its member states (as reported in Appendix).

As rights and duties change from a region to another, this provides room for employers and farmers to play with these varying and shifting conditions. Strategies of substitution of migrant groups according to criteria such as nationality, gender and legal status have continuously availed the agricultural sector of a cheap and vulnerable workforce. Literature reports about cases whereby the replacement of some groups with others are linked with attempts to restrict collective action and negotiation power of the former (Lindner and Kathmann 2014; Lenoël 2014; Sampedro and Camarero 2015; Caruso 2016b; Corrado 2017).

\subsection{Rights at Stake}

Several studies and reports point out to the largely informal contractual relationships and the precarious living and working conditions that characterize EUMed rural areas and that involve illegal hiring, low wages, high workloads, and suboptimal working and living conditions (Baldwin-Edwards and Arango 1999; King et al. 2000; OECD 2012; Colloca and Corrado 2013; Gertel and Sippel 2014; Corrado et al. 2018). Social researchers have been increasingly working to document the systematic denial of the basic rights of women and men which underpin most of EUMed's agricultural system. These conditions imply high social costs for the whole society, undermining the social acceptance of certain agricultural systems as well as their sustainability (Ortiz-Miranda et al. 2013; Gertel and Sippel 2014; Corrado et al. 2016, 2018; Nori 2017; Oxfam 2018). The exploitative nature of the restructuring of agricultural labour markets in the EUMed remains, however, still largely invisible to consumers and to citizens.

Reports are that several immigrants in EUMed agriculture often work for 10-12 h a day, for a wage that is considerably below the legal minimum one. Amongst the many difficulties and problems experienced by precarious immigrant workers in rural areas of the EUMed, a main one is linked to the absence of inclusive policies. In most agricultural intensive areas, immigrant workers live in rural slums, isolated and socially segregated from local populations. "Ghetto economies" is the name given to these highly exploitative situations where migrant workers are forced to live in appalling makeshift living conditions (Mangano 2014). The high concentration of 
precarious migrants in slums largely impacts on their capacity to integrate into local societies, and contributes generating racialized tensions and violences (i.e. the infamous episodes of El Ejido in Spain in 2001, Castelvolturno in 2008 and Rosarno in 2010 in Italy, and Manolada in Greece in 2013 amongst many others). According to Corrado et al. (2018: 24):

The recurrent episodes of violence or racism by local populations towards seasonal workers - highlight the ambiguous coexistence of economic demand for migrant labour in the fields and social hostility to their presence in the streets. Wage gaps, precariousness, marginalisation and extreme flexibility are recurring elements in all Mediterranean countries but are play out differently in the different context.

For those residing far from the working fields, rural mobility and transportation represents another form of exploitative condition; costly and unsafe transportation services have resulted in numerous fatal accidents for the workers. Altogether, housing and transportation have caused dozens of deaths of immigrant workers in southern Italy in recent decades.

Other situations exist whereby farmers provide housing on the farms, subtracting these and other living costs from the wage of workers (e.g. in livestock farms). These immigrant workers living in isolated farms in the countryside suffer often loneliness and isolation.

Unhealthy working conditions might add up to physical exhaustion from excessive hours. Agricultural workers engaged in farms, barns and greenhouses are exposed to harmful chemicals, pesticides, and fertilizers. Illnesses and injuries associated include heat and water stress from working in the hot sun, exposure to cold and wet conditions during winter times, long-term chemical exposure under greenhouse plastic that emits harmful fumes.

Recruitment and engagement in the labour market are also domains where immigrants might face high costs and risks, as the official channels of employment are oftentimes ineffective. In Italy this has generated the phenomenon of 'caporalato'.

\section{Box: The Caporalato System}

The "caporalato" is a labour contracting system in the informal sector in Italy. An intermediary coordinating the relationship between migrants and farm owners, is part of the caporalato system. This system is traditionally characterized in harvesting of tomatos and citrus fruits in the South of Italy (Colloca and Corrado 2013; Pugliese 2012; Perrotta and Sacchetto 2013; Perrotta 2015; Corrado et al. 2018) and has become widespread as well in the wine sector in Northern Italy (Mangano 2013; Donatiello and Moiso 2017).

An emblematic case is the tomato harvesting in Apulia (Perrotta 2016). The seasonal pickers live in informal slums in rural areas, often far from villages, and are typically paid on a per-piece basis (i.e. 3-4€ for every $300 \mathrm{~kg}$ box of picked tomatoes). 
The workers are prevalently from sub-Saharan Africa and are recruited by different caporalato systems, organized often by other immigrants. The caporale (illegal or informal labour contractor) intermediates between the workers and the farmers, or may organize a work-team with relatives, friends and members of the same national community. According to the farmers, the caporalato system, also provides the housing and transportation for workers (often paid on the workers' dairy salary), which creates opportunities for further harassment, considering the absence of other means of transport to reach the land.

According to Perrotta (2016), this system in the tomato sector is the result of different factors including: (i) a lack of a public recruitment system; (ii) the inefficiency of the supply chain organizations and the small size of tomato processors; (iii) the pressure from retailers; (iv) the absence of investment in the mechanization of harvesting operations.

A Law approved in 2016 has defined the "caporalato" as a crime and has forged legal instruments accordingly.

These critical factors tend though to remain largely unaddressed because new supplies of precarious immigrant workers are constantly available. Since seasonal immigrants coming to the EUMed from Africa, Asia and Eastern Europe face oftentimes problems with their legal status and related vulnerabilities, they can easily become victims of blackmailing and several other forms of exploitation. The replacement and circulation of workers remains high, both because there is a large "reserve army" and because agriculture remains a "buffer" sector, where immigrants take refuge when they lose a safer job.

Despite these negative aspects, agriculture continues to be seen as an area of opportunity for immigrants to enter the labour market. After this broad introduction on the conditions of immigrant labour in the agriculture sector in the EUMed, we now turn to more specific analyses in the three EUMed countries: Greece, Spain and Italy.

\subsection{Country Cases: Greece, Spain and Italy}

\subsubsection{Greece}

The agricultural sector in Greece is considered a source of supplementary income for Greek workers and represents a buffer for local rural economies where non-farm employment is unstable. Agriculture still provides vital support for a significant number of rural areas in Greece (Kasimis 2010). Changes in the rural economy over the past three decades, however, have triggered a restructuring of rural Greek society, whereby the massive rural exodus of the 1960's and the expansion of 
other, non-agricultural activities have caused labour shortages that have not been filled by the local population in rural Greece (Kasimis et al. 2010; Kasimis 2010:261). ${ }^{2}$

New transnational immigrants have thus come to fill this gap by replacing the vanishing local population. In Greece, immigrants cover seasonal labour needs, contribute to increasing agricultural production, and help to keep wages and agricultural product prices low (Lianos et al. 1996; Vaiou and Hadjimichalis 1997). The geographical proximity of Albania to Greece, led to the development of a circular migration and recruitment system of Albanian labourers in Greece (Labrianidis and Sykas 2009) in the late 1990s. The studies carried out by Kasimis et al. (2003, 2010) in the early 2000s offer interesting insights into the economic and social implications of the settlement and employment of migrant labour in rural areas.

Immigrants played diverse roles in the survival of Greek agriculture and the maintenance of the rural social fibre. Their versatile skills and geographical mobility over multiple seasons provided a highly flexible labour force supporting the survival, expansion and modernisation of farms. The availability of a migrant workforce helps counterbalance the outmigration of the local workforce, keeping production costs low and thus enabling the agricultural activities to continue even in marginal settings, such as in the mountainous areas and the islands that cover a large part of the Greek territory (Kasimis and Papadopoulos 2005; Kasimis et al. 2010; Ragkos et al. 2016). Some of the contributions of immigrants to the social fibre of rural Greek communities include the revival of traditions through the use of traditional materials, and the demographic renewal of marginal rural areas through introducing higher fertility rates and through intermarriage with local residents (Kasimis 2009; Kasimis et al. 2010; Gallo and Rioja 2016).

Initial inflows of Albanians have been followed by those of Bulgarians and Romanians, and more recently by refugees who have reached Greece from neighbouring war-torn regions. Particularly in the aftermath of the recent economic crises, these more recent groups of immigrants have increased their geographical mobility between different rural areas in response to their precarious position, labour insecurity, and low socio-economic status (Papadopoulos 2012; Papadopoulos and Fratsea 2016). Several bilateral agreements have facilitated a process of seasonal/ circular movement with Albania, Bulgaria, and Egypt (Triandafyllidou 2013) coming to rural Greece to work. The introduction of a three-month visa for Albanian nationals has made it easier for them to take up seasonal work in peak seasons, but some may end up working without legal status. Every 2 years a joint ministerial decision sets the maximum amount of positions for seasonal employment by region and sector. Non-EU citizens can be admitted to work for a maximum of 6 months through an "invitation" or "call" system (metaklisi), for which it is however difficult to apply for (Corrado et al. 2018).

\footnotetext{
${ }^{2}$ Relevant sources for data on migrants' presence in the Greek rural setting include the Hellenic Statistical Office (ELSTAT), the Greek Ministry of Migration Policy as well as the Hellenic Foundation or European and Foreign Policy (ELIAMEP, www.eliamep.gr).
} 
In April 2016, the law was amended (Art. 13a Law 4251/2014) so that farmers/ employers in regions where seasonal working positions exist, and have already been approved, may recruit irregular third-country nationals or asylum seekers already resident in Greece. This thus has enabled the regular employment of irregular migrants by providing them with a temporary, 6-month permit (Papadopoulos and Fratsea 2017). This device is however criticised as it generates even further dependence on employers, since when that period expires, the suspension is lifted and the rights of workers are lost (Corrado et al. 2018).

\section{Box: Strawberry Production in Manolada}

As Corrado et al. (2018) note strawberry production in Manolada is characterized by a significant expansion and greenhouse systems. Several factors have contributed to the growth in strawberry cultivation: the replacement of fresh strawberry plants with frozen ones, thus allowing for a longer harvest period and better organoleptic characteristics; the establishment of an exportoriented cooperative; and, finally, the availability of cheap and flexible migrant labour (Papadopoulos and Fratsea 2016).

While the number of Albanian, Bulgarian and Romanian workers in Manolada has progressively decreased, the amount of Bangladeshis has increased. Predominantly single males, with very low educational profiles, Bangladeshi migrants live in collective houses or in makeshift tents. Most of them are without legal status, which significantly increases their vulnerability to exploitation.

In 2013, 150 Bangladeshi workers went on strike in Manolada to claim unpaid wages. The companies's armed guards fired on the protesting workers, severely injuring 30 of them. The case was brought before the European Court of Human Rights (ECHR), which in 2017 judged on that Bangladeshi migrant workers' conditions were those of forced labour and human trafficking (Corrado et al. 2018).

Greek was accused of violating article 4 of the European Convention on Human Rights, but no significant measures have been implemented to prevent and address this form of exploitation so far. That same year, Open Society foundation in partnership with a Greek NGO Generation 2.0 initiated a paralegal project with a view to build a community infrastructure in Manolada, by providing, amongst other measures, mobile legal clinics to address legal needs and rights issues of migrant workers (Corrado et al. 2018). 


\subsubsection{Spain}

The recent growth of immigrant workers in rural areas started in the 1980s and 1990s when Spanish agriculture became more intensive. In the early 2000s, immigration increased further, spurred by the economic crisis in 2008 that collapsed opportunities for employment in other sectors (for example the construction sector). Today, immigrants contribute between one quarter and one third of the salaried agricultural workforce in Spain, these include many precarious workers. These workers contribute significantly to enhancing productivity in the agricultural sector as well as to reverse depopulation trends, ensuring the survival of local economies in many rural areas (Collantes et al. 2014). ${ }^{3}$

While rural immigrants mostly contribute to agriculture production in the intensive systems that characterise the Southern regions of the country, they also represent a relevant and increasingly appreciated resource to maintain populations in rural villages, especially in remote areas (e.g. the Nuevos Senderos program ${ }^{4}$ ) (on the Spanish case see Hoggart and Mendoza 1999; Esparcia 2002; García Coll and Sánchez 2005; Solé 2010; Prieto and Papadodima 2010; Camarero et al. 2013; Collantes et al. 2014; Gallo and Rioja; 2016). The mobility of rural migrants is concentrated around three main hubs: (i) the neighbouring provinces of the eastern area: Murcia, Alicante, Albacete and Almería; (ii) between Barcelona and the Catalan provinces of Tarragona and Girona; (iii) between Valencia, Alicante, Castellón and Barcelona (Observatorio de las Ocupaciones 2014; Viruela and Torres Pérez 2015; Caruso and Corrado 2015).

The rural agricultural labour market in Spain is complex in terms of spatial and temporal organization. The local labour market is segmented, with different migrant groups competing with each other and with local workers in the different agricultural areas in different work-intensive periods, from the winter harvest of olives and the spring harvest of strawberries, to other vegetables and fruits, but this also applies to variation in labour requirements in livestock breeding systems. Circular mobility schemes amongst different agricultural areas mostly include provinces of Andalucía and Catalonia.

Traditionally, many low-wage agricultural workers came from Latin America and the Middle East and North Africa, specifically Morocco (Checa 2001; Hellio 2016). In recent years, there has been an intensifying presence of immigrants from sub-Saharan Africa and from Eastern Europe as well as Asian countries in rural areas, as a result of the economic crisis discussed earlier which made urban employment options less available in migrants' home regions.

Spain is an interesting case because the recruitment of seasonal migrant workers is stimulated and managed by national policies, like those in non-European countries

\footnotetext{
${ }^{3}$ Relevant sources for data on migrants' presence in the Spanish rural setting includes the Instituto Nacional Estadistico (INE) with its Encuestas de Variaciones Residenciales, the Observatorio Mercado Trabajo (OMT), and the Observatorio Permanente de la Inmigración (OPI).

${ }^{4} \mathrm{http} / / /$ cepaim.org/que-hacemos-convivencia-social/desarrollo-rural/nuevos-senderos-empleorural/
} 
including the US, Canada, and Australia (Martin 2016). In Spain, the seasonal workers are recruited directly in their countries of origin through a "contratación en origen" and a quota system known as the Régimen General and the FNAAC (Framework National Agreement on Seasonal Workers for Agriculture Campaigns). On the surface, this model seems to be a flexible and consensual system matching the demand and the offer of labour through public governance that includes public institutions, private actors and business associations (as intermediaries). However, similar to other national programs based on quota policies restricting the amount and length of stay of internationally recruited workers, this model exposes immigrant labourers to high levels of exploitation and abuse: the immigrants became strongly dependent upon intermediaries and employers.

As summarized by Corrado et al. (2018: 25):

the private intermediation of farmworkers is ensured by Temporary Employment Agencies (Empresas de trabajo temporal, ETT) regulated by Law No. 14/1994), which largely control contracts in areas like Valencia or Murcia. During a harvesting season, workers can have several contracts. ETTs move workers across regions, provinces, or countries and play a fundamental role in the ethnic segmentation, replacement, and rotation of the labour force to ensure flexibility but also causing job insecurity.

Many researches investigate this system of exploitation, including Moreno (2009 2012), Martin (2016), Pumares and Jolivet (2014), Reigada (2016), Gadea et al. (2016), Avallone and Ramirez-Melgarejo (2017), Corrado (2017).

\section{Box: Immigrants Substitution in Spanish Agriculture: The Case of Huelva}

Following Lindner and Kathmann (2014: 127) "over the last two decades, Huelva has emerged as Europe's most developed strawberry-growing region, annually producing 260,000 tons of strawberries - roughly 35 per cent of the entire European production. If the autumnal work of planting requires 1.000 workers, at least 60.000 labourers are needed for harvesting". By the end of the 1980s foreign workforce started substituting the Spanish one, as agricultural work was associated to a low social status. It was then mostly Moroccans residing in Spain that came to contribute their labour to this sector, a less vindictive and cheaper workforce compared to the local one. In the same period Spanish women started to engage in the previously men-dominated packaging industry.

As a result of the riots in El Ejido (Almeria province) in 2000, which involved Moroccan agricultural labourers demanding for better working and living conditions, agricultural entrepreneurs in most of Southern Spain started looking for 'less conflictive' and 'more adaptable' labour migrants. In the early 2000s workers from some Latin American countries (such as Ecuador) but mostly from Eastern Europe (mostly Poland and Romania) increasingly entered the Spanish agricultural labour markets, substituting the Moroccan 
workforce. As to Lindner and Kathmann (2014: 128) "for several years, in the spring months, bus caravans from Poland and Romania brought thousands of women to Huelva to meet the demand for labour; 7.000 Polish women in 2002 were taken to Huelva. The least productive workers were sent back after 15 days of trial or when they were no longer needed for the harvest peaks".

Following the enlargement of the EU in 2007, and with the acquisition of better rights, Eastern European women were less bound to seasonal work in agriculture. Their substitution begun thus through these seasonal labour migration schemes denominated contraction en origen whereby female workers were directly recruited in the rural areas of Morocco, preferably with young children - as a critical incentive to return home by the end of the temporary contract (Hellio 2016; Caruso 2016a). The interplay between Romanian and Moroccan female workers that has characterised recent years, until the more recent entry of irregular African migrants into the Spanish agricultural labour market, has provided further availability of a cheap workforce.

\subsubsection{Italy}

Although it is not easy to ascertain these data according to CREA (2017) the amount for foreign workers in Italian agriculture was around 405.000 in 2015 , +5\% compared to $2014.27 \%$ of these are women, and over $40 \%$ of the immigrant workers are found in Northern Italy. As to Table 3.3 EU citizens remain the most numerous migrant workers in Italy (over 211.000 people), with a modest recent increase compared to those who are not citizens of the EU. In particular, the growing amount of Eastern European workers is due to the EU enlargement that has facilitated the entry of Romanian workers, whereas many refugees have become agricultural workers in the last 2 years. ${ }^{5}$

Table 3.3 Migrant workers in Italian agriculture by country of origin

\begin{tabular}{l|l|l}
\hline Country of origin & 2008 & 2016 \\
\hline Romania & 77.250 & 112.289 \\
\hline India & 9.867 & 26.900 \\
\hline Albania & 17.018 & 24.870 \\
\hline Morocco & 14.435 & 23.932 \\
\hline Poland & 24.708 & 15.986 \\
\hline Bulgaria & 14.482 & 12.036 \\
\hline
\end{tabular}

Source: INPS data elaboration, 2016 in Corrado et al. 2018

\footnotetext{
${ }^{5}$ Relevant sources for data on migrants' presence in the Italian rural settings include Osservatorio Placido Rizzotto (OPR), Istituto Nazionale di Statistica (ISTAT), Istituto Nazionale Economia Agraria (INEA), Caritas.
} 
Agricultural workers employed without an official contract are estimated at 430.000, of whom around 80\% were foreign workers and about 100.000 were identified as being at a high risk of exploitation. Women comprise about $42 \%$ of farm workers without legal documentation and are usually over-represented in unpaid and seasonal work (Dines and Rigo 2015; Medu 2015; OPR 2018; Oxfam 2018).

There are many differences between the conditions for workers in the different Italian regions: in Southern Italy, the workers are employed in harvesting and the work is irregular, informal and seasonal. In the Northern regions, workers are employed in the intensive livestock breeding sector, and the labour is more continuous and durable. According to Corrado (2017), non-EU workers tend to be young men employed in low-skilled horticultural jobs requiring physical strength. But women from non-EU nations are also employed, especially in Southern Italy in packing and processing jobs. This is particularly true in Sicily, where there is a consistent amount of immigrants engaged in agriculture (about 47,000 workers according to CREA). Research has documented the exploitation of Romanian female workers in greenhouses where they are often victims of blackmail and violence (see e.g. Palumbo and Sciurba 2015; Piro and Sanò 2016; Sanò 2018).

In the seasonal work patterns in Southern Italy, especially in Calabria and Puglia, but also in Sicily and Basilicata, workers are underpaid and official contracts only record and report a part fo the story, in kinds of 'grey' arrangements. Even when the immigrants have signed a regular contract, the declared hours and working days are reduced by the employees, increasing the exploitation and precluding the possibility to accrue social rights and benefits.

The case of Southern Italy is emblematic due to its seasonal and progressively specialized agriculture. In Calabria, Sicily, Campania, Apulia, and Basilicata openair or greenhouse seasonal productions of fruits and vegetable rely mainly on small and medium-sized farms; products are oriented to fresh consumption or processing and serve distant distribution and corporate retailers. Furthermore, in agriculture, as much as in the general economy, the labour market in Southern Italy is characterized by informal contractual relationships. The immigrants move from one place to another depending on the seasonality of harvesting tomatoes, oranges, lemons, grapes and other fruit and vegetables.

Much research has documented the exploitation of immigrant people, in particular the non-European workers (that are often without legal documentation and thus more easily blackmailed) through the caporalato system in which immigrants are informally hired for very little money or through other forms of exploitation (AA. VV. 2012; Colloca and Corrado 2013; Pugliese 2012; Perrotta and Sacchetto 2013; Perrotta 2015; Corrado et al. 2018).

Another way in which a precarious labour supply is organized for farmers is through temporary staffing agencies, or service agencies (particularly organizing the labour of Romanian workers) and through the mechanism of the so-called «landless cooperatives». This is a way to hire immigrant workers from Eastern Europe for the seasonal harvest. They are engaged as «worker members» of the cooperatives (that in Italy have a special and facilitated tax regime), thus employees manage to evade 
social security obligations, minimum legal wages, and labour laws regarding working hours. The research of Caruso (2016b) and Perrotta (2014) investigated the phenomenon of "landless cooperatives" in the South. Recently, Donatiello and Moiso (2017) have documented the same mechanisms in the harvest of grapes in Canelli (Piedmont in the North) for the production of D.O.C. (Protected Designation of Origin, certified through a quality control system) wine. The Macedonian migrants who have settled in Canelli for several years have a fairly stable status, and have organized a system of exploitation of other workers from Eastern Europe (in particular the Romanians) who are hired seasonally through landless cooperatives and are mostly precarious, exploited and underpaid.

The systems described (caporalato system, the landless cooperatives, and the staffing agencies) indicate important degrees of collusion amongst various agents of the agriculotural sector, as well as the complacency of a legal and policy framework that provide an enabling environment for grey practices at the expenses of immigrant workers.

This collusion between immigrant labour brokers and farmers is highlighted by Avallone $(2016,2017)$ in the case of the Piana del Sele in Campania, where immigrants work in greenhouses that produce pre-mixed salads for supermarkets. In this area, the "decreto flussi" - the Italian programme for the recruitment of foreign seasonal workers - has often been used by local farmers and illegal brokers to cheat migrants and the state alike. The local market is segmented by nationality and gender. Male workers from Morocco (the first to work in this area) are today stressed by competition with Romanian immigrants who accept lower salaries: the daily wage $(7 \mathrm{~h})$ varies from 27 to 33 Euros and the monthly salary ranges between 500 and 800 Euros (Avallone 2016).

Another field of research analyses the extensive production of canned tomatoes in the area of Vulture-Alto Bradano in Basilicata, which has employed many African people (Burkina Faso, Mali, Ghana, Tunisia, Morocco are the most frequent countries of workers' origin) (Perrotta 2016). The cases of lemon and orange harvests in Calabria illustrate some of the same patterns described above (see box).

\section{Box: Picking Citrus Fruits in the Plains of Sibari and Rosarno, Calabria}

According to Corrado (2017), in the Calabria region migrants are employed in the winter for harvesting lemons and oranges, with some local differences. This agri-food chain is exposed to major concentration in large scale distribution and to a high pressure from the global market that calls for a high volatility of orange prices, inefficient delivery, and flexible workers available to answer to the «just-in-time» demands of supermarkets (Garrapa 2016). In this sense, the work is very precarious, unstable and informal, involving different kind of vulnerable immigrant workers, who may or may not have legal status (as asylum seekers with temporary international protection, «rejected asylum seekers», or refugees, including minors, who have evaded identification 
procedures, Corrado and D’Agostino 2018). Many workers from African nations arrive in Calabria after the end of the tomato harvest season in Puglia and Basilicata, and after the end of the citrus season they move on, either to Campania or to Sicily, living in rural temporary camps that are real slums.

In the Plain of Sybaris, the harvest operations start in November and last until to July, with several different crop harvests (starting with the harvesting of olives, oranges and clementines, then pruning and grafting operations, and finally the peach and strawberry harvests). The immigrant workers come mainly from the Maghreb (Tunisia and Morocco) and from Eastern Europe (Romania, Bulgaria, and Ukraine), with differences in wages and working conditions between different groups of immigrants, as well as between them and local workers, demonstrating race-gender segregation in agriculture:

The African workers receive, on average, 20-25 euros per day, [and] those from Eastern Europe... earn up to 35 euros, while [local] workers receive around 40 euros. The workday is generally $10-15$ hours; piece rate work, paying 5 euros per box, is also common. Informal brokers (caporali) can retain up to 10 euros for their role in intermediation, transport and the provision of basic goods such as water. Women from Eastern Europe are paid 1,50-2,50 euros per hour (while men receive up to 3 euros) and work around eight hours a day. Some employers prefer to hire womenonly teams: Their wages are lower, they are more consistent in their work activity, and they achieve higher work and production rates. Women leaving their children at home are often selected, because after the harvest season they tend to return home. That said, women in the field are often victims of sexual abuse and violence (Corrado 2017: 6).

In Calabria, we find some of the most difficult working conditions in an area of intensive orange production: the Plain of Rosarno is known for the first riots of sub-Saharan African pickers of oranges in 2010 (with clashes with the local population), countered by the national government with the forced relocation to other regions of 1,500 immigrant strikers.

As Corrado (2017: 7) has explained well, "the cut in EU subsidies for fruit production, coupled with a decline in market price for low-quality oranges used by the juice industry - from 1400 lire per kilo in 1999 to 10-20 cents in 2010, to the current price of 5-6 cents - due to low-cost imports from Brazil and Spain, has further discouraged harvesting. Because of this crisis, many growers are now converting to higher-value produce, such as kiwi, and Eastern European women are largely employed to harvest this new product".Furthermore, in the last years, there is a process of replacing African workers with Eastern Europeans both because they are willing to accept lower wages, and because since 2009, changes in migration laws have made it more convenient to hire these workers to avoid legal problems, since they can have legal status as members of EU nations. 


\subsection{Conclusions: Dynamics, Trends and Roles for Immigrants in Rural Areas}

The Mediterranean is traditionally a region shaped by and through migrations. Its European shores have long been an area of emigration and have become today the nodal point of migratory flows to Europe. However, the European shores of the Mediterranean are not just a transit area, but also an attractive stop for migrants due to the high demand for low-skilled labour in agriculture.

The demand for cheap labour is particularly high in the regions where agricultural labour is normally temporary and precarious, requiring workers to move according to seasonal agricultural demands. Depopulating rural areas in the EU have become a haven for precarious, migrant workforce, as access to food, accommodation and employment can be less of a barrier than in traditional urban centers. In southern Europe, the agricultural workforce today mainly originates from North Africa and Eastern Europe, although recent flows involve refugees from conflict-ravaged areas and poor economic conditions, such as from countries deeper into the Asian and African continents.

This comes, however, with a cost. Under growing pressure from large production and distribution systems, agricultural producers tend to reduce production costs by employing low-paid labour under exploitative conditions. This results in agricultural systems that systematically deny the rights of workers, women and men, especially immigrants, who enjoy fewer citizenship rights, reduced salary and exploitative labour conditions.

Many studies point out to the 'grey' contractual relationships and the precarious conditions that characterize these working environments and to the related extensive social costs. These in turn generate stress in relationships between foreigners and local populations, as well as between immigrants of different national origins, and undermine the overall sustainability of this sector. This is particularly ironic when these exploitative practices take place in a sector that enjoys consistent public support through the CAP and other policies.

Migration patterns have been changing rapidly during the recent financial crisis and are likely to continue increasing in coming years for several reasons including political, economic and climatic ones. These flows will continue providing an important 'reserve army' for a sector that maintains salaries and rights low through mechanisms of substitution and replacements. 


\section{Appendix: The Conditions of Migrant Workers}

Migration strategies differ depending on the specific rights and capacities the diverse communities might enjoy in the EU setting, in terms of concern circular migration patterns, family re-unification options, development of transnational networks, access to different services and opportunities, opportunities for local investments and entrepreneurial initiatives, etc.... These patterns carry important consequences on the communities of origin as well in EUMed countries.

Several mobility rights and duties are related to the Schengen framework, while others relate to countries' bilateral agreements.

\begin{tabular}{|c|c|c|c|}
\hline Rights & $\begin{array}{l}\text { Recent EU } \\
\text { citizens } \\
\text { (ie. Romanians, } \\
\text { Bulgarians) }\end{array}$ & $\begin{array}{l}\text { UE enlargment areas } \\
\text { (ie. Macedonians, } \\
\text { Albanians) }\end{array}$ & $\begin{array}{l}\text { EU Neighbourhood } \\
\text { (ie. Moroccans, Tunisians) }\end{array}$ \\
\hline $\begin{array}{l}\text { Access and } \\
\text { mobility }\end{array}$ & $\begin{array}{l}\text { Unconditional } \\
\text { rights; free } \\
\text { circulation }\end{array}$ & $\begin{array}{l}\text { Need for a Visa and related } \\
\text { negotiation - although this } \\
\text { process is being simplified } \\
\text { due to Visa liberalisation } \\
\text { throughout the Schengen } \\
\text { area (e.g. Albanians no } \\
\text { need visa below } 3 \text { months } \\
\text { staying). }\end{array}$ & $\begin{array}{l}\text { Need for a Visa and related } \\
\text { negotiations within bilat- } \\
\text { eral agreements - Cooper- } \\
\text { ation on simplifying the } \\
\text { procedures for access for } \\
\text { certain categories of peo- } \\
\text { ple (including the possibil- } \\
\text { ity of issuing multiple- } \\
\text { entry and longer-term } \\
\text { visas, and waiving } \\
\text { administration fees). }\end{array}$ \\
\hline $\begin{array}{l}\text { Residential } \\
\text { (above } \\
3 \text { months) }\end{array}$ & $\begin{array}{l}\text { Since } 2013 \text { EU } \\
\text { citizens }\end{array}$ & $\begin{array}{l}\text { Residential rights associ- } \\
\text { ated to a) work permit or b) } \\
\text { attachment o resident fam- } \\
\text { ily member with whom } \\
\text { there is direct dependency } \\
\text { relationship - to be negoti- } \\
\text { ated within the framework } \\
\text { of bilateral agreements. }\end{array}$ & $\begin{array}{l}\text { Residential rights associ- } \\
\text { ated to: a) work permit or } \\
\text { b) attachment o resident } \\
\text { family member with whom } \\
\text { there is direct dependency } \\
\text { relationship - Cooperation } \\
\text { on simplifying the proce- } \\
\text { dures for legal stays for } \\
\text { certain categories of peo- } \\
\text { ple to be negotiated within } \\
\text { the framework of coun- } \\
\text { tries' bilateral } \\
\text { agreements. }\end{array}$ \\
\hline $\begin{array}{l}\text { Labour market - } \\
\text { including possi- } \\
\text { bility to set up an } \\
\text { enterprise }\end{array}$ & $\begin{array}{l}\text { Since } 2013 \\
\text { unconditional } \\
\text { rights }\end{array}$ & $\begin{array}{l}\text { Simplified procedure for } \\
\text { some countries (e.g. no } \\
\text { need for visa renewal after } \\
3 \text { initial months). Possibility } \\
\text { to get long-term residency } \\
\text { and related } \\
\text { non-discriminatory rights } \\
\text { after } 5 \text { years of demon- } \\
\text { strated legal presence in the } \\
\text { country. }{ }^{.}\end{array}$ & $\begin{array}{l}\text { Need to continuously } \\
\text { renew residential visa. } \\
\text { Possibility to get long-term } \\
\text { residency and related } \\
\text { non-discriminatory rights } \\
\text { after } 5 \text { years of demon- } \\
\text { strated legal presence in } \\
\text { the country. }\end{array}$ \\
\hline
\end{tabular}




\begin{tabular}{l|l|l|l}
\hline & $\begin{array}{l}\text { Recent EU } \\
\text { citizens } \\
\text { (ie. Romanians, } \\
\text { Bulgarians) }\end{array}$ & $\begin{array}{l}\text { UE enlargment areas } \\
\text { (ie. Macedonians, } \\
\text { Albanians) }\end{array}$ & $\begin{array}{l}\text { EU Neighbourhood } \\
\text { (ie. Moroccans, Tunisians) }\end{array}$ \\
\hline $\begin{array}{l}\text { Family } \\
\text { reunification }\end{array}$ & $\begin{array}{l}\text { Unconditional } \\
\text { rights }\end{array}$ & $\begin{array}{l}\text { Possibility to invite family } \\
\text { members after at least } \\
1 \text { year of legal residence } \\
\text { subject to bilateral restric- } \\
\text { tions (related to } \\
\text { (a) accommodation, } \\
\text { (b) health insurance, } \\
\text { (c) financial capacities). } \\
\text { Process simplified within } \\
\text { the ongoing Visa } \\
\text { liberalisation negotiations. }\end{array}$ & $\begin{array}{l}\text { Possibility to invite family } \\
\text { members after at least } \\
1 \text { year of legal residence } \\
\text { subject to bilateral restric- } \\
\text { tions (related to } \\
\text { (a) accommodation, } \\
\text { (b) health insurance, } \\
\text { (c) financial capacities). }\end{array}$ \\
\hline
\end{tabular}

Source: Our elaboration, thanks to G. Renaudiere

${ }^{a}$ As part of the Stabilisation and Association Process (SAP) in 1999 and the EU Enlargement policy ${ }^{b}$ EU-Morocco mobility partnership (and the 9 participating Member States: the Kingdom of Belgium, the French Republic, the Federal Republic of Germany, the Italian Republic, the Kingdom of the Netherlands, the Portuguese Republic, the Kingdom of Spain, the Kingdom of Sweden, and the United Kingdom), June 2013 (http://ec.europa.eu/dgs/home-affairs/what-is-new/news/news/ 2013/docs/20130607_declaration_conjointe-maroc_eu_version_3_6_13_en.pdf)

${ }^{\mathrm{c}}$ Nationals of these countries, who are working legally in the European Union, are entitled to the same working conditions as the nationals

\section{References}

Ambrosini, M. (2013). Irregular migration and invisible welfare. Houndmills: Palgrave Macmillan. Arrighi, G. (1985). Semiperipheral development: The politics of Southern Europe in the twentieth century (explorations in the world economy). Beverly Hills: Sage.

Avallone, G. (2016). The land of informal intermediation. The social regulation of migrant agricultural labour in the Piana del Sele, Italy. In A. Corrado, C. de Castro, \& D. Perrotta (Eds.), Migration and agriculture: Mobility and change in the Mediterranean area. London: Routledge.

Avallone, G. (2017). Sfruttamento e resistenze: Migrazioni e agricoltura in Europa, Italia, Piana del Sele. Verona: Ombre Corte.

Avallone, G., \& Ramirez-Melgarejo, A. (2017). Trabajo vivo, tecnología y agricultura en el sur de Europa. Una comparación entre la Piana del Sele en Salerno (Italia) y la Vega Alta del Segura en Murcia (España). Ager. Revista de Estudios sobre Despoblación y Desarrollo Rural, 23, 131-161. https://doi.org/10.4422/ager.2017.06

AA.VV. (2012). Brigate di solidarietà attiva). Sulla pelle viva. Nardò: la lotta autorganizzata dei braccianti agricoli. Roma: Derive\&Approdi.

Baldwin-Edwards, M., \& Arango, J. (Eds.). (1999). Immigrants and the informal economy in Southern Europe. Portland: Frank Cass. 
Bell, M. M., \& Osti, G. (2010). Mobilities and ruralities: An introduction. Sociologia Ruralis. Special Issue on Mobilities and Ruralities, 50(3), 199-204. https://doi.org/10.1111/j.1467-9523. 2010.00518.x.

Camarero, L., Sampedro, R., \& Oliva, J. (2013). Trayectorias ocupacionales y residenciales de los inmigrantes extranjeros en las áreas rurales españolas. Sociología del Trabajo, 77, 69-91.

Caruso, F. (2016a). Fragole amare: lo sfruttamento del bracciantato migrante nella provincia di Huelva. In Osservatorio Placido Rizzotto (Ed.), Agromafie e Caporalato. Terzo rapporto. Roma: Ediesse.

Caruso, F. (2016b). Dal caporalato alle agenzie di lavoro temporaneo: i braccianti rumeni nell'agricoltura mediterranea. Mondi Migranti, 1(3), 51-64. https://doi.org/10.3280/MM2016003004.

Caruso, F., \& Corrado, A. (2015). Migrazioni e lavoro agricolo: un confronto tra Italia e Spagna in tempi di crisi. In M. Colucci \& S. Gallo (Eds.), Tempo di cambiare. Rapporto 2015 sulle migrazioni interne in Italia. Roma: Donzelli.

Castles, S., \& Kosack, G. (1973). Immigrant workers and class structure in Western Europe. Oxford: Oxford University Press.

Castles, S., \& Miller, M. J. (1993). The age of migration: International population movements in the modern world. London: Macmillan.

Checa, F. (2001). El Ejido: la ciudad cortijo. Claves socioeconómicas del conflicto étnico. Barcelona: Icaria Editorial.

Collantes, F., Pinilla, V., Sàez, L. A., \& Silvestre, J. (2014). Reducing depopulation in rural Spain. Population, Space and Place, 20, 606-621. https://doi.org/10.1002/psp.1797.

Colloca, C., \& Corrado, A. (Eds.). (2013). La globalizzazione delle campagne. Migranti e società rurali nel Sud Italia. Milano: FrancoAngeli.

Colucci, M., \& Gallo, S. (Eds.). (2015). Tempo di cambiare. Rapporto 2015 sulle migrazioni interne in Italia. Roma: Donzelli.

Corrado, A. (2015). Lavoro straniero e riorganizzazione dell'agricoltura familiare in Italia. Agriregionieuropa, 43, 23-27. https://agriregionieuropa.univpm.it/it/content/article/31/43/ lavoro-straniero-e-riorganizzazione-dellagricoltura-familiare-italia.

Corrado, A. (2017). Migrant crop pickers in Italy and Spain. E-paper, Heinrich Böll Stiftung Foundation. Berlin. https://www.boell.de/sites/default/files/e-paper_migrant-crop-pickers-initaly-and-spain.pdf

Corrado, A., \& D'Agostino, M. (2018). Migrations in multiple crisis. New development patterns for rural and inner areas in Calabria (Italy). In K. Stefan, W. Tobias, \& I. Jelen (Eds.), Processes of immigration in rural Europe: The status Quo, implications and development strategies (pp. 272-295). Cambridge: Cambridge Scholars Publishing.

Corrado, A., De Castro, C., \& Perrotta, D. (Eds.). (2016). Mobility and change in the Mediterranean area. London/New York: Routledge.

Corrado, A., Palumbo L., Caruso F. S., lo Cascio M., Nori M., \& Traindafyllidou, A. (2018). Is Italian agriculture a 'Pull Factor' for irregular migration and, if so, why? Open Society Foundations. https://www.opensocietyfoundations.org/sites/default/files/is-italian-agriculturea-pull-factor-for-irregular-migration-20181205.pdf. Accessed 20 Jan 2019.

CREA. (2017). Annuario dell'agricoltura italiana 2015. Roma: Crea.

De Zulueta, T. (2003). Migrants in irregular employment in the agricultural sector of Southern European countries. Report for the debate in the standing committee. Bruxelles: Council of Europe.

Dines, N., \& Rigo, E. (2015). Postcolonial citizenships between representation, borders and the 'refugeeization' of the workforce: Critical reflections on migrant agricultural labor in the Italian Mezzogiorno. In S. Ponzanesi \& G. Colpani (Eds.), Postcolonial transitions in Europe: Contexts, practices and politics (pp. 151-172). London: Rowman and Littlefield. 
Donatiello, D., \& Moiso, V. (2017). Titolari e riservisti. L'inclusione differenziale di lavoratori immigrati nella viticultura del Sud Piemonte. Meridiana, 89, 185-210.

ELSTAT. (2013). Hellenic statistical office. Athens: Coincise Statistical Yearbook.

Esparcia, J. (2002). La creciente importancia de la inmigración en las zonas rurales de la comunidad valenciana. Cuadernos de Geografía, 72, 289-306.

Farinella, D., Nori, M., \& Ragkos, A. (2017). Change in Euro-Mediterranean pastoralism: Which opportunities for rural development and generational renewal? In C. Porqueddu, A. Franca, G. Molle, G. Peratoner, \& A. Hokings (Eds.), Grassland reources for extensive farming systems in marginal lands: Major drivers and future scenarios (Grassland Science in Europe) (Vol. 22, pp. 23-36). Wageningen: Wageningen Academic Publishers.

Ferrera, M. (1996). The 'southern model' of welfare in social Europe. Journal of European Social Policy, 6(1), 17-37. https://doi.org/10.1177/095892879600600102.

Gadea, E., Pedreño, A., \& de Castro, C. (2016). Producing and mobilizing vulnerable workers. The agribusiness of the region of Murcia (Spain). In A. Corrado, C. De Castro, \& D. Perrotta (Eds.), Migration and agriculture. Mobility and change in the Mediterranean area. London: Routledge.

Gallo, R. S, \& Rioja, L. C. (2016). Inmigrantes, estrategias familiares y arraigo: las lecciones de la crisis de las areas Rurales. Migraciones, 39, 3-31. mig.i40y2016.00840services.

García Coll, A., \& Sánchez, D. (2005). La población rural en Cataluña: entre el declive y la revitalización. Cuadernos Geográficos, 36(1), 387-407.

Garrapa, A. M. (2016). Braccianti just in time. Raccoglitori stagionali a Rosarno e Valencia. Firenze: La Casa Usher.

Gertel, J., \& Sippel, R. S. (Eds.). (2014). Seasonal workers in Mediterranean agriculture: The social costs of eating fresh. London: Routledge.

Hellio, E. (2016). They know that you'll leave, like a dog moving onto the next bin: Undocumented male and seasonal contracted female workers in the agricultural labour market of Huelva, Spain. In A. Corrado, C. de Castro, \& D. Perrotta (Eds.), Migration and agriculture. Mobility and change in the Mediterranean area (pp. 198-216). London: Routledge.

Hoggart, K., \& Mendoza, C. (1999). African Immigrant Workers in Spanish Agriculture. Sociologia Ruralis, 39(4), 538-556. https://doi.org/10.1111/1467-9523.00123.

ILO. (2015, December 15). ILO global estimates of migrant workers. www.ilo.org/global/topics/ labourmigration/publications/WCMS_436343/lang\%2D\%2Den/index.htm

Jentsch, B., \& Simard, M. (Eds.). (2009). International migration and rural areas. Cross-national comparative perspectives. London: Ashgate.

Kasimis, C. (2009). From enthusiasm to perplexity and scepticism: international migrants in the rural regions of Greece and Southern Europe. In B. Jentsch \& M. Simard (Eds.), International migration and rural areas (pp. 75-98). London: Ashgate.

Kasimis, C. (2010). Demographic trends in rural Europe and migration to rural areas. AgriRegioniEuropa, 6/21. https://agriregionieuropa.univpm.it/it/content/article/31/21/demo graphic-trends-rural-europe-and-international-migration-rural-areas

Kasimis, C., \& Papadopoulos, A. G. (2005). The multifunctional role of migrants in the Greek countryside: Implications for the rural economy and society. Journal of Ethnic and Migration Studies, 31(1), 99-127. https://doi.org/10.1080/1369183042000305708.

Kasimis, C., \& Zografakis, S. (2012). Return to the land: Rural Greece as refuge to crisis. XIII world congress on rural sociology. IRSA, Lisboa.

Kasimis, C., Papadopoulos, A. G., \& Zacopoulou, E. (2003). Migrants in rural Greece. Sociologia Ruralis, 43(2), 167-184. https://doi.org/10.1111/1467-9523.00237. 
Kasimis, C., Papadopoulos, A. G., \& Pappas, C. (2010). Gaining from rural migrants: Migrant employment strategies and socio-economic implications for rural labour markets. Sociologia Ruralis, 50(3), 258-276. https://doi.org/10.1111/j.1467-9523.2010.00515.x.

King, R. (2000). Southern Europe in the changing global map of migration. In R. King, G. Lazaridis, \& C. Tsardanidis (Eds.), Eldorado or Fortress? Migration in Southern Europe (pp. 3-26). London: Palgrave Macmillan.

King, R., Lazaridis, G., \& Tsardanidis, C. (Eds.). (2000). Eldorado or fortress? Migration in Southern Europe. London: Palgrave Macmillan.

Labrianidis, L., \& Sykas, T. (2009). Geographical proximity and immigrant labour in agriculture: Albanian immigrants in the Greek countryside. Sociologia Ruralis, 49(4), 394-414. https://doi. org/10.1111/j.1467-9523.2009.00494.x.

Lenoël, A. (2014). Burden or empowerment? The impact of migration and remittances on women left behind in Morocco. PhD, Social Policy, University of Bristol.

Lewis, W. A. (1958). Economic development with unlimited supplies of labour. In A. N. Agarwal \& S. P. Singh (Eds.), The economics of underdevelopment (pp. 400-449). Oxford: Oxford University Press.

Lianos, T. P., Sarris, A. H., \& Katseli, L. T. (1996). Illegal immigration and local labour markets: The case of Northern Greece. International Migration, 34(3), 449-484. https://doi.org/10.1111/ j.1468-2435.1996.tb00537.x.

Lindner, K., \& Kathmann, T. (2014). Mobility partnerships and circular migration: Managing seasonal migration to Spain. In J. Gertel \& R. S. Sippel (Eds.), Seasonal workers in Mediterranean agriculture: The social costs of eating fresh. London: Routledge.

Mangano, A. (2013). Piemonte: la vendemmia della vergogna. L'Espresso, 3 December. http:// espresso.repubblica.it/inchieste/2013/12/03/news/il-prestigioso-vino-piemontese-e-prodottocome-a-rosarno-1.144081

Mangano, A. (2014). Ghetto economy. Edizioni: Createspace Independent Publishing.

Martin, C. (1996). Social welfare and the family in Southern Europe. South European Society \& Politics, 1(3), 23-41. https://doi.org/10.1080/13608749638539481.

Martin, P. L. (2016). Migrant workers in commercial agriculture. Geneva: ILO. https://www.ilo. org/wcmsp5/groups/public/\%2D\%2D-ed_protect/\%2D\%2D-protrav/\%2D\%2D-migrant/docu ments/publication/wcms_538710.pdf

Medu. (2015). Terraingiusta. Rapporto sulle condizioni di vita e di lavoro dei braccianti stranieri in agricoltura. www.mediciperidirittiumani.org/pdf/Terraingiusta.pdf

Mingione, E. (1995). Labour market segmentation and informal work in Southern Europe. European Urban and Regional Studies, 2, 121-143. https://doi.org/10.1177/ 096977649500200203.

Mingione, E., \& Quassoli, F. (2000). The participation of immigrants in the underground economy in Italy. In R. King, G. Lazaridis, \& C. Tsardanidis (Eds.), Eldorado or fortress? Migration in Southern Europe (pp. 29-56). London: Palgrave Macmillan.

Moreno, J. (2009). Los contratos en origen de temporada. Mujeres marroquíes en laagricultura onubense. Revista de Estudios Internacionales Mediterráneos, 7, 58-78.

Moreno, J. (2012). Movilidad transnacional, trabajo y género: temporeras marroquíes en la agricultura onubense. Política y Sociedad, 49(1), 123-140. https://doi.org/10.5209/rev_poso. 2012.v49.n1.36525.

Naldini, M. (2003). The family in the Mediterranean welfare state. London: Frank Cass.

Natale, F., Kalantaryan, S., Scipioni, M., Alessandrini, A., \& Pasa, A. (2019). Migration in EU rural areas (EUR 29779 EN). Luxembourg: Publications Office of the European Union. https:// doi.org/10.2760/544298. 
Nori, M. (2017). Immigrant Shepherds in Southern Europe. E-paper, Heinrich Böll Stiftung Foundation. https://www.boell.de/en/agriculture-food-production-and-labour-migration-south ern-europe

Observatorio de las Ocupaciones. (2014). Datos básicos de movilidad Contratación y movilidad geográfica de los trabajadores en España Datos 2013. Madrid: Servicio Público de Empleo Estatal.

OECD. (2012). Indicators of immigrant integration. Paris: OECD Publishing. https://doi.org/10. 1787/9789264171534-en.

OECD. (2018). How immigrants contribute to developing countries' economies. Paris: OECD Publishing.

OPR-Osservatorio Placido Rizzotto. (2018). Agromafie e Caporalato. Quarto Rapporto. Roma: Ediesse.

Ortiz-Miranda, D., Moragues, F. A., \& Arnalte-Alegre, E. (Eds.). (2013). Agriculture in Mediterranean Europe: Between old and new paradigms (Research in Rural Sociology and Development) (Vol. 19). Bingley: Emerald Group Publishing Limited.

Osti, G., \& Ventura, F. (Eds.). (2012). Vivere da stranieri in aree Fragili. Napoli: Liguori.

Oxfam. (2018). Human suffering in Italy's agricultural value chain. Oxfam International \& Terra!

Palumbo, L., \& Sciurba, A. (2015). Vulnerability to forced labour and trafficking: The case of Romanian women in the agricultural sector in Sicily. Anti-Trafficking Review, 5, 89-110. https://doi.org/10.14197/atr.20121556.

Papadopoulos, A. G. (2012). Transnational immigration in rural Greece: Analysing the different mobilities of Albanian immigrants. In C. Hedberg \& R. M. do Carmo (Eds.), Translocal ruralism: Mobility and connectivity in European rural spaces (pp. 163-183). Dordrecht: Springer.

Papadopoulos, A. G., \& Fratsea, L. M. (2016). Appraisal of migrant labour in intensive agricultural systems: The case of Manolada strawberries (Greece). In A. Corrado, C. de Castro, \& D. Perrotta (Eds.), Migrations and agriculture. Mobility and change in the Mediterranean area (pp. 128-144). London: Routledge.

Papadopoulos, A. G., \& Fratsea, L. M., (2017). Temporary migrant workers in Greek agriculture. E-paper, Heinrich Böll Stiftung Foundation. https://www.boell.de/sites/default/files/e-paper_ temporary-migrant-workers-in-greek-agriculture.pdf

Perrotta, D. (2014). Vecchi e nuovi mediatori. Storia, geografia ed etnografia del caporalato in agricoltura. Meridian, 79, 193-220. https://doi.org/10.1400/221104.

Perrotta, D. (2015). Agricultural day laborers in Southern Italy: Forms of mobility and resistance. South Atlantic Quarterly, 114(1), 195-203. https://doi.org/10.1215/00382876-2831632.

Perrotta, D. (2016). Processing tomatoes in the era of the retailing revolution. Mechanization and migrant labour in northern and southern Italy. In A. Corrado, C. de Castro, \& D. Perrotta (Eds.), Migrations and agriculture. Mobility and change in the Mediterranean Area (pp. 58-75). London: Routledge.

Perrotta, D., \& Sacchetto, D. (2013). Les ouvriers agricoles étrangers dans l'Italie méridionale. Hommes et migrations, 1301, 57-66. https://doi.org/10.4000/hommesmigrations.1910.

Pigot, M. (2003). Decent work in agriculture. http://www.ilo.org/wcmsp5/groups/public/—ed_ dialogue/—actrav/documents/publication/wcms_111457.pdf

Piore, M. J. (1979). Birds of passage: Migrant labour and industrial societies. Cambridge: Cambridge University Press.

Piro, V., \& Sanò, G. (2016). Entering the "plastic factories". Conflicts and competition in Sicilian greenhouses and packinghouses. In A. Corrado, C. de Castro, \& D. Perrotta (Eds.), Migrations and agriculture. Mobility and change in the Mediterranean Area (pp. 293-308). London: Routledge. 
Prieto, S., \& Papadodima, Z. (2010). Reversión (comparativa) del despoblamiento rural a través de las migraciones internacionales. AGER. Documento de Trabajo $n^{\circ} 28$.

Pugliese, E. (1993). Restructuring of the labour market and the role of Third World migrations in Europe. Environment and Planning D Society and Space., 11, 513-522. https://doi.org/10.1068/ d110513.

Pugliese, E. (2000). The Mediterranean model of immigration (Academicus MMXI/3, pp. 97-106). http://www.academicus.edu.al/nr3/Academicus-MMXI-3-096-107.pdf

Pugliese, E. (2012). Diritti Violati. Indagine sulle condizioni di vita dei lavoratori immigrati in aree rurali del Sud Italia e sulle violazioni dei loro diritti umani e sociali. Dedalus Cooperativa Sociale.

Pumares, P., \& Jolivet, D. (2014). Origin matters: working conditions of Moroccans and Romanians in the greenhouses of Almeria. In J. Gertel \& S. R. Sippel (Eds.), Seasonal workers in Mediterranean agriculture. The social cost of eating fresh (pp. 130-140). New York: Routledge.

Ragkos, A., Koutsou, S., \& Manousidis, T. (2016). In search of strategies to face the economic crisis: Evidence from Greek farms. South European Society and Politics, 21, 319-337. https:// doi.org/10.1080/13608746.2016.1164916.

Reigada, A. (2016). Family farms, migrant labourers and regional imbalance in global agri-food systems. On the social (un)sustainability of intensive strawberry production in Huelva (Spain). In A. Corrado, C. de Castro, \& D. Perrotta (Eds.), Migrations and agriculture. Mobility and change in the Mediterranean area (pp. 95-110). London: Routledge.

Salazar Parreñas, R. (2001). Servants of globalization. Stanford: Stanford University Press.

Sampedro, R. (2013). Spatial distribution of foreign labor immigrants in rural areas: Exploring the potential of towns and villages to retain them in the long run. In AA.VV. (Ed.), Proceedings of the XXV conference of the European Society for Rural Sociology. Pisa: Laboratorio di studi rurali Sismondi.

Sampedro, R., \& Camarero, L. (2015). International immigrants in rural areas: The effect of the crisis in settlement patterns and family strategies. Proceedings of the XXVI Congress of the European Society for Rural Sociology, Aberdeen (UK).

Sanò, G. (2018). Fabbriche di plastica. Il lavoro nell'agricoltura industriale. Verona: Ombre Corte.

Schmoll, C., Thiollet, H., \& Wihtol de Wenden, C. (Eds.). (2015). Migrations en Méditerranée/ migration in the Mediterranean. Paris: CNRS editions.

Schrover, M., Van der Leun, J., \& Quispel, C. (2007). Niches, labour market segregation, ethnicity and gender. Journal of Ethnic and Migration Studies, 33(4), 529-540. https://doi.org/10.1080/ 13691830701265404 .

SOFA. (2018). State of food and agriculture 2018 on migration, agriculture and rural development. Rome: FAO, Food and Agriculture Organization. http://www.fao.org/3/I9549EN/ i9549en.pdf.

Solé, A. (2010). Características sociodemográficas, pautas de distribución territorial y proceso migratorio de la población de nacionalidad extranjera en el Alt Pirineu i Aran: contribuciones a la transformación de un espacio de montaña. AGER. Documento de trabajo, 290.

Triandafyllidou, A. (2013). Circular migration between Europe and its neighbourhood: Choice or necessity? Dordrecht: Oxford University Press.

UN DESA. (2017). Trends in international migrant stock: The 2017 revision (United Nations database, POP/DB/MIG/Stock/Rev.2017). New York: United Nations, Department of Economic and Social Affairs.

Vaiou, D., \& Hadjimichalis, K. (1997). With the sewing machine in the kitchen and the poles in the fields: Cities, regions and informal labour. Athens: Exandas. 
Viruela, R., \& Torres, P. F. (2015). Flujos migratorios, crisis y estrategias de movilidad. Los inmigrantes ecua- torianos y rumanos en España. In F. Torres Pérez \& E. Gadea (Eds.), Crisis, Inmigración, Sociedad (pp. 37-72). Madrid: Editorial Talasa.

Zuccotti, C. V., Geddes, A. P., Bacchi, A., Nori, M., \& Stojanov, R. (2018). Rural migration in Tunisia. Drivers and patterns of rural youth migration and its impact on food security and rural livelihoods in Tunisia. Rome: Food and Agriculture Organization of the United Nations.

Open Access This chapter is licensed under the terms of the Creative Commons Attribution 4.0 International License (http://creativecommons.org/licenses/by/4.0/), which permits use, sharing, adaptation, distribution and reproduction in any medium or format, as long as you give appropriate credit to the original author(s) and the source, provide a link to the Creative Commons license and indicate if changes were made.

The images or other third party material in this chapter are included in the chapter's Creative Commons license, unless indicated otherwise in a credit line to the material. If material is not included in the chapter's Creative Commons license and your intended use is not permitted by statutory regulation or exceeds the permitted use, you will need to obtain permission directly from the copyright holder. 